\title{
QUALIDADE DE HORTÍCOLAS CONVENCIONAIS, ORGÂNICAS E HIDROPÔNICAS NA REGIÃO METROPOLITANA DE CURITIBA, PARANÁ ${ }^{1}$
}

\author{
STERTZ, S.C. ${ }^{2}$; FREITAS, R.J.S. ${ }^{3}$
}

1.Resumo da Tese de Doutorado da primeira autora. Defendida em 17 de junho de 2004.

2.Doutora em Tecnologia de Alimentos - Programa de Pós-graduação em Tecnologia de Alimentos UFPR - Química, Pesquisadora da UFPR - Setor de Tecnologia, Departamento de Engenharia Química, Universidade Federal do Paraná - Caixa Postal 19011 CEP 81531-990 Curitiba PR - Brasil. E-mail: stertz@ufpr.br.

3.Doutor em Engenharia Química DEQ/UPR -Professor do Programa de Pós-Graduação em Tecnologia de Alimentos DEQ - UFPR. (orientador)

A agricultura da Região Metropolitana de Curitiba (RMC) está voltada basicamente para a produção de hortícolas, respondendo por $50 \%$ da produção do Estado do Paraná. O problema é que, parte desses alimentos têm apresentado resíduos de agrotóxicos, agravando a crise da agricultura convencional $(\mathrm{C})$. Visando atender à demanda alimentar da população e às tendências do mercado atual, a ciência agrícola tem fundamentado novas formas de cultivo de hortícolas, como a agricultura orgânica $(\mathrm{O})$ e a hidropônica $(\mathrm{H})$ entre outras. Além dos resíduos de agrotóxicos, conteúdo de nitrato, matéria seca e vitamina C, existem poucas evidências de que alimentos orgânicos, convencionais e hidropônicos diferem em suas concentrações de nutrientes, havendo necessidade de novos e criteriosos estudos. O objetivo desse trabalho foi avaliar comparativamente os sistemas de cultivo praticados na RMC, além de analisar a qualidade de hortícolas convencionais, orgânicas e hidropônicas, produzidas e/ou comercializadas na RMC. Foram monitoradas 10 culturas de hortícolas em relação à ausência de toxicidade, aspecto nutricional e estrutural. De um modo geral, os dados obtidos nas análises físicoquímicas mostraram grande variação, o que pode justificar os altos valores para o desvio padrão. Em muitos casos, o desvio padrão excedeu a média, fato que pode explicar a não ocorrência de diferença estatística significativa $(p \leq 0,05)$ entre algumas das amostras analisadas, quando comparadas em relação ao sistema de cultivo. As maiores diferenças entre os sistemas de cultivo foram observadas em relação aos micronutrientes, principalmente nas culturas de tomate salada e morango. Essas amostras não apresentaram diferenças estatísticas significativas $(p \leq 0,05)$, quando comparados os sistemas de cultivo convencional e orgânico, diferindo, porém das amostras obtidas pelo sistema de cultivo hidropônico, que apresentaram teores mais elevados. As concentrações de nitritos e nitratos nas culturas analisadas apresentaram a seguinte relação: alface, tomate cereja e tomate tipo salada $-\mathrm{O}<\mathrm{C}<\mathrm{H}$; espinafre, morango e batata - $\mathrm{O}<\mathrm{C}$; agrião - $\mathrm{C}<\mathrm{H}<\mathrm{O}$; couve-flor, cenoura e pepino - $\mathrm{CO}$. Considerando a IDA em relação aos nitritos e nitratos, as culturas de agrião, alface e espinafre foram as que apresentaram as maiores restrições ao consumo, variando de 81 e $100 \mathrm{~g}$ para o agrião orgânico e hidropônico, 330 e $148 \mathrm{~g}$ para a alface convencional e hidropônica e 192 a $301 \mathrm{~g}$ para o espinafre convencional e hidropônico, respectivamente. As hortícolas cultivadas pelo sistema de produção orgânico, convencional e hidropônico apresentaram, respectivamente, $9,68 \%, 33,87 \%$ e $41,18 \%$ de suas amostras com algum tipo de resíduo de agrotóxicos. Independente do sistema de cultivo, todas as amostras de agrião analisadas apresentaram reação positiva para o dissulfeto de carbono $\left(\mathrm{CS}_{2}\right)$. Porém, indícios de possível "falso positivo" evidenciaram a necessidade de testes confirmatórios para cada molécula. As amostras de agrião, alface e tomate cereja apresentaram diferenças estruturais quantitativas segundo o sistema de manejo em que foram cultivadas. O cultivo orgânico mostrou ser o que apresenta maior massa tanto nas folhas de Nasturtium officinale e Lactuca sativa quanto no fruto de Lycopersicum esculentum var. cerisiforme.

Palavras-chave: Agrotóxicos; Análise Estrutural; Contaminantes; Controle de Qualidade; Hortícolas; Sistemas de Cultivo. 


\section{ABSTRACT \\ QUALITY OF HORTICULTURAL CONVENTIONAL, ORGANICS AND HYDROPONICS AT METROPOLITAN AREA OF CURITIBA - PARANÁ}

The agriculture of the Metropolitan Area of Curitiba (MAC) is basically characterized by horticultural production, being responsible for $50 \%$ of the Paraná state total production. The problem is that part of those foods has been presenting pesticides residues, worsening the crisis of the conventional agriculture (C). Seeking to assist to the alimentary demand of the population and the tendencies of the current market, the agricultural science has been developing new forms of cultivation of horticultural, as the organic agriculture $(\mathrm{O})$ and the hydroponics $(\mathrm{H})$ among other. Except for pesticides residues, nitrate content, dry matter and vitamin $\mathrm{C}$, there are no strong evidences that organic, conventional and hydroponics foods differ in their concentrations of nutrients, being required new and improved studies. The aim of the present work was to comparatively evaluate the cultivation systems practiced in MAC, besides analyzing the quality of conventional, organic and hydroponics produced and/or commercialized at MAC. Ten horticultural cultures were monitored in relation to toxicity absence, nutritional and structural aspect. In a general way, the data obtained by physical-chemical analysis showed great variation, what can justify the high values obtained for standard deviation. In many cases, the standard deviation exceeded the average, fact that can explain the occurrence of no significant statistical difference $(p \leq 0.05)$ among some of the analyzed samples, when compared in relation to the cultivation system. The largest differences among the cultivation systems were observed in relation to the micronutrients, mainly in tomato and strawberry cultures. Those samples didn't present significant statistical differences $(p \leq 0.05)$, when compared conventional and organic cultivation systems, even so differing of the samples obtained by hydroponics cultivation system that presented higher contents. The nitrite and nitrate concentrations in the analyzed cultures presented the following relation: lettuce, cherry tomato and tomato - $\mathrm{OCH}$; spinach, strawberry and potato - OC; water cress $\mathrm{CHO}$; cauliflower, carrot and cucumber - $\mathrm{C} \mathrm{O}$. Considering ADI (acceptable daily intakes) in relation to nitrites and nitrates, water cress, lettuce and spinach cultures were the ones that presented the largest restrictions to consumption, varying of about 81 and $100 \mathrm{~g}$ for the organic and hydroponic water cress, 330 and $148 \mathrm{~g}$ for conventional and hydroponic lettuce and 192 to $301 \mathrm{~g}$ for conventional and hydroponic spinach, respectively. The horticultural cultivated by organic, conventional and hydroponics system presented respectively, $9.68 \%, 33.87 \%$ and $41.18 \%$ of the samples with some pesticide residue. Independently of the cultivation system all analyzed samples of water cress showed positive reaction to carbon disulfide $\left(\mathrm{CS}_{2}\right)$. Although indications of possible "false positive" evidenced, the confirmatory tests to each molecule are necessaries. The water cress, lettuce and cherry tomato showed quantitative structural differences according to the handling system in which they were cultivated. The organic cultivation presents larger mass even in the leaves of Nasturtium officinale and Lactuca sativa as in the fruit of Lycopersicum esculentum var. cerisiforme

Key-words: Pesticides; Structural Analysis; Contaminants; Quality Control, Horticultural; Cultivation Systems. 


\section{RÉSUMÉ}

\section{QUALITE DES HORTICOLES CONVENTIONELLES, BIOLOGIQUES ET HYDROPONIQUES DE LA REGION METROPOLITAINE DE CURITIBA PARANÁ}

L'agriculture de la Région Métropolitaine de Curitiba (RMC) est caractérisé par la production horticole fondamentalement et est responsable pour $50 \%$ de la production totale de l'état du Paraná. Le problème est que une partie de ces aliments ont présenté restes des pesticides, agravant la crise de l'agriculture conventionnelle (C). Vouloir prendre en consideration à la demande alimentaire de la population et les tendances du marché courant, la science agricole a développé nouvelles formes de culture d'horticole, comme l'agriculture biologique $(B)$ et la culture hydroponique $(\mathrm{H})$ parmi autre. $\grave{A}$ l'exception de restes des pesticides, concentration de nitrate, matière séche et vitamine $C$, il n'y a pas de fortes evidences que les aliménts biologiques, conventionnelles et hydroponiques différent dans leurs concentrations d'éléments nutritifs, en faisant nécessaire des études nouveaux et detaillés. Le objectif de ce travail était évaluer comparativement les systèmes de culture pratiqué dans la RMC, au-delà d'analyser la qualité des horticoles conventionelles, biologiques et hydroponiques, qu'ont été produit et/ou commercialisé à la RMC. Dix cultures horticoles ont été dirigées par rapport à l'absence de toxicité, aspect alimentaire et structurel. D'une façon générale, les données obtenus par analyse physique-chimique ont montré une grande variation, ce qui peut justifier les hautes valeurs obtenus pour la déviation standarde. Dans plusiers cas, la déviation standarde a dépassé la moyenne, fait que peut expliquer l'événement d'aucune différence statistique considérable $(p \leq 0,05)$ parmi des échantillons analysés, quand comparé par rapport au système de culture. Les plus grandes différences parmi les systèmes de culture ont été observées par rapport au micro-éléments nutitifs, principalement dans les cultures de tomate et de la fraise. Ces échantillons n'ont pas présenté de différences statistiques considérables $(p \leq 0,05)$, quand les systèmes de culture conventionnel et biologique ont été comparés et est différent des échantillons obtenu par le système de culture hydroponique qui a présenté de plus haut contenu. Les concentrations de nitrates et de nitrites dans les cultures analysées ont présenté la relation suivante: laitue, tomate groseille et tomate - $\mathrm{BCH}$; épinards, fraise et pomme de terre - BC; cresson de la terre CHB; chou-fleur, carotte et concombre - CB. Étant donné I'IAJ(ingestion acceptable par jour) par rapport à des nitrites et des nitrates, les cultures de cresson de la terre, laitue et d'épinards ont présenté les plus grandes restrictions à consommation et varient approximativement de 81 et $100 \mathrm{~g}$ pour le cresson de la terre biologique et hydroponique, 330 et $148 \mathrm{~g}$ pour la laitue conventionnelle et hydroponique et 192 à $301 \mathrm{~g}$ pour l'épinard conventionnel et hydroponique, respectivement. Les horticoles cultivés par le système biologique, conventionnel et hydroponique ont présenté respectivement, $9.68 \%, 33.87 \%$ et $41.18 \%$ des échantillons avec quelque reste du pesticide. Indépendamment du système de culture tout les échantillons de cresson de la terre analysés ont montré la réaction positive à disulfure de carbone $\left(\mathrm{CS}_{2}\right)$. Bien que, indications de possibles "faux positif " ont evidencer le besoin de testes de confirmation pour chaque molécule. Le cresson de la terre, la laitue et le tomate groseille ont montré des différences structurelles quantitatives d'après le système de manutention dans qu'ils ont été cultivés. La culture biologique a présente la plus grande masse dans les feuille de Nasturtium officinale et Lactuca sativa comme dans les fruits de Lycopersicum esculentum var. cerisiforme.

Les mot-clefs: Les pesticides; L'Analyse structurelle; Contaminant alimentaire; Contrôle de la qualité, Horticoles; Les Systèmes de culture. 